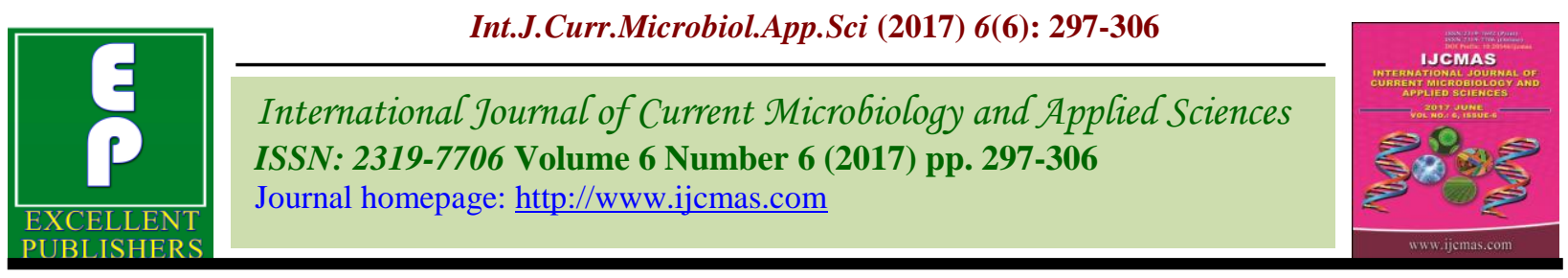

Original Research Article

https://doi.org/10.20546/ijcmas.2017.606.036

\title{
Yield and Economics of Rice (Oryza sativa L.) as Influenced by Establishment Methods and Varieties under Mollisols of Pantnagar
}

\author{
D.K. Singh ${ }^{*}$, P.C. Pandey, Shanker Dutt Thapliyal and Gangadhar Nanda \\ Department of Agronomy, G. B. Pant University of Agriculture and Technology, \\ Pantnagar, Uttarakhand- 263 145, India \\ *Corresponding author
}

\section{A B S T R A C T}

\section{Keywords}

Transplanted rice,

Direct seeded riceaerobic,

Direct seeded rice

on FIRB,

Wet direct seeded rice,

Yield,

Economics.

Article Info

Accepted:

04 May 2017

Available Online:

10 June 2017
The present investigation was carried out during kharif season of 2015 and 2016 in split-plot design with four establishment methods namely wet-direct seeded (Wet DSR), direct seeded aerobic (DSR-aerobic), direct seeded on furrow irrigated raised bed (DSR on FIRB) and transplanted (TP) in main plots and eight rice cultivars (Pant Dhan 23, Pant Dhan 24, Pant Shankar Dhan 1, Pant Shankar Dhan 3, Pusa Basmati 1, Pusa 1121, Govind and Pant Dhan 26) in sub-plots taking 3 replications. Result revealed that highest grain and straw yield was recorded under TP in both years. The increment in grain yields over wet DSR and DSR-aerobic were 7.63 and $11.29 \%$ and 10.75 and $15.64 \%$ in 2015 and 2016, respectively. The maximum gross return (Rs. 83972 and $84552 \mathrm{ha}^{-1}$ ) and net return (Rs. 50636 and $51216 \mathrm{ha}^{-1}$ ) was obtained in TP while the benefit cost ratio (1.80 and 1.71) was found maximum with DSR-aerobic during 2015 and 2016. Highest grain and straw yield was obtained with hybrid variety Pant Shankar Dhan 3 for both years except 2015 where Pant Dhan 24 recorded maximum straw yield. The maximum gross return (Rs. 85218 and 90685 ha-1) and net return (Rs. 55108 and 60575 ha1) was recorded in variety Pant Shankar Dhan 3 in 2015 and 2016. Growing rice hybrid Pant Shankar Dhan 3 under conventional transplanting can give higher grain yield.

\section{Introduction}

Rice is the staple food crop for more than $50 \%$ of world population (Fageria, 2007) and is the most important cereal crop of India covering an area of 43.9 mha with production and productivity of 106.5 million tonnes and $2424 \mathrm{~kg} \mathrm{ha}^{-1}$, respectively (Anonymous, 2014). Cultivation of rice with conventional transplanting requires huge amount of irrigation water ranging from 1,500 and 3,000 mm (Sharma et al., 2002; Singh et al., 2002). With declining water resources and increasing demand for other competitive users of water like for domestic and industrial use, there will be water crisis in near future. So, alternative rice production technology with low water input is needed. In wet-direct seeded rice, seeds are either broadcasted or sown in line using drum seeder. To feed the ever increasing population we have to constantly increase the food grain production of which rice constitutes a major role. In this regard role of varieties has profound influence on the 
productivity and thereby meeting the rice production demand. There are different types of rice cultivars like hybrids, high yielding varieties and basmati rice of various durations suitable to particular area and consumers demand. Moreover, high yielding varieties have multiple resistances to the biotic (insects and diseases) and abiotic stresses like drought, salinity/alkalinity tolerance etc. Among several types of rice, basmati rice is regarded as the king of rice and it fetches higher price due to better organoleptic quality characteristics. The demand of this type of rice is also high is other countries (Singh et al., 2017). The availability of short-duration rice cultivars has lead to large increases in cropping intensity, greater on-farm employment, increased food supplies and higher food security in many major riceproducing countries (Khush, 2001). Different varieties viz. hybrid, high yielding, basmati and short duration varieties show different behaviour under different establishment methods which needs to be experimented.

\section{Materials and Methods}

The experiment was conducted during kharif season of 2015 and 2016 in A2 block at N. E. Borlaug Crop Research Centre, G. B. Pant University of Agriculture and Technology, Pantnagar, Uttarakhand. Geographically, it is located at $290 \mathrm{~N}$ latitude and $79.290 \mathrm{E}$ longitudes and an altitude of 243.84 metre above mean sea level. Soil of the experimental field was silty loam in texture and is of alluvial origin and classified as Aquic Hapludoll (Deshpande et al., 1971). The chemical analysis of upper $20 \mathrm{~cm}$ soil showed that it was high in organic carbon, low in available $\mathrm{N}$, medium in available phosphorus and potassium and slightly alkaline in soil reaction (Table 1). The experiment was laid out in split-plot design with four establishment methods namely wetdirect seeded (Wet DSR), direct seeded aerobic (DSR-aerobic), direct seeded on furrow irrigated raised bed (DSR on FIRB) and transplanted (TP) in main plots and eight rice cultivars including two high yielding varieties (Pant Dhan 23 and Pant Dhan 24), two hybrids (Pant Shankar Dhan 1 and Pant Shankar Dhan 3), two Basmati varieties (Pusa Basmati 1 and Pusa 1121) and two high yield short duration varieties (Govind and Pant Dhan 26) in sub-plots taking 3 replications.

The experimental field was prepared by ploughing once by disc plough followed by cross disc harrowing twice, after that the field was levelled. Certified seeds of variety Pant Dhan 23, Pant Dhan 24, Pant Shankar Dhan 1, Pant Shankar Dhan 3, Pusa Basmati 1, Pusa 1121, Govind and Pant Dhan 23 with different seed rates were sown as per table 2 in different establishment methods. Furrows were opened manually at $20 \mathrm{~cm}$ distance in direct seeded aerobic, direct seeded on FIRB plots and in wet direct seeded puddle plots, pre-germinated seeds were broadcasted as per treatment. After seeding, furrows in direct seeded plots were covered properly (manually) with soil. Twenty four days old seedlings were transplanted in puddled field using two seedlings hill ${ }^{-1}$ at a spacing of 20 $\mathrm{cm} \times 20 \mathrm{~cm}$. After 10 days of sowing the missing plants in the rows as per treatment were replanted (gap filling) with the seedling uprooted for the same plot where it had high density. Recommended dose of fertilizer i.e. 120-60-40 N- $\mathrm{P}_{2} \mathrm{O}_{5}-\mathrm{K}_{2} \mathrm{O}$ was applied in the experimental plots. Before seeding, $25 \% \mathrm{~N}$ $\left(30 \mathrm{~kg} \mathrm{~N} \mathrm{ha}^{-1}\right)$, full dose of phosphorus $(60 \mathrm{~kg}$ $\mathrm{P}_{2} \mathrm{O}_{5} \mathrm{ha}^{-1}$ ) and potassium (40 kg $\mathrm{K}_{2} \mathrm{O} \mathrm{ha}^{-1}$ ) was applied through urea $(46 \% \mathrm{~N})$, NPK mixture (12: 32: 16) and muriate of potash $\left(60 \% \mathrm{~K}_{2} \mathrm{O}\right)$, respectively and incorporated into soil. The remaining quantity of nitrogen (90 $\mathrm{kg} \mathrm{N} \mathrm{ha}^{-1}$ ) was top dressed in two splits: at tillering $\left.(60 \mathrm{~kg} \mathrm{~N} \mathrm{ha})^{-1}\right)$ and panicle initiation $\left(30 \mathrm{~kg} \mathrm{~N} \mathrm{ha}^{-1}\right)$ stages in wet direct seeded, direct seeded-aerobic and direct 
seeded on furrow irrigated raised bed rice and in transplanted rice, $50 \% \mathrm{~N}\left(60 \mathrm{~kg} \mathrm{~N} \mathrm{ha}{ }^{-1}\right)$ applied as basal, remaining quantity of nitrogen $\left(60 \mathrm{~kg} \mathrm{~N} \mathrm{ha}^{-1}\right)$ was top dressed in two splits: at tillering $\left(30 \mathrm{~kg} \mathrm{~N} \mathrm{ha}^{-1}\right)$ and panicle initiation $\left(30 \mathrm{~kg} \mathrm{~N} \mathrm{ha}^{-1}\right)$ stages. Irrigation was given by flooding method, pre-sowing irrigation was given into the field for preparation of seed bed and water was given as per need to maintain condition of the soil, rest excess water was drained out from the field time to time during crop season in direct seeded-aerobic, direct seeded on FIRB and wet-direct seeded rice and soil moisture was maintained near about saturation at sowing to milk stage. While in transplanted rice, a thin film of water $(2-3 \mathrm{~cm})$ was maintained during initial stage up to seedling establishment, thereafter, plots were kept continuously flooded and irrigated whenever required in order to maintain a ponded layer of 5-6 cm depth during the vegetative stage and after panicle initiation, $2-3 \mathrm{~cm}$ depth of water was maintained in bed and plots were drained 15 days before harvest. Pendimethalin @ $1 \mathrm{~kg}$ a.i. was mixed in 750 litre water and was sprayed next day of sowing as pre-emergence and bispyribac sodium @ $0.25 \mathrm{~kg}$ a.i. $\mathrm{ha}^{-1}$ in 750 to 1000 litre of water was sprayed at 15 20 days after sowing (DAS) as pre-emergence in DSR-aerobic and DSR on FIRB methods and pretilachlor@0.75 kg a.i. ha ${ }^{-1}$ in 750 to 1000 litre of water was sprayed at 6 DAS as pre-emergence in wet direct seeded method and 1-3 days after transplanting (DAT) in transplanted plots to control the weeds. Two weedings were done at 20 and 40 days after sowing by removing weeds manually using a khurpi. To control Khaira ( $\mathrm{Zn}$ deficiency), two sprays of zinc $(5 \mathrm{~kg}$ zinc sulphate with $2.5 \mathrm{~kg}$ slaked lime dissolved in 1000 litre water/ha) were done at 15 and 25 days after emergence. For iron deficiency especially in DSR plots, $\mathrm{FeSO}_{4}$ was applied @ $0.5 \%$ at 20 days after emergence. There was no serious problem of insect-pest except mild incidence of stem borer which was controlled timely by applying Cartap hydrochloride (Calden-G) @ $20 \mathrm{~kg} \mathrm{ha}^{-1}$. Crop from the net plot area were harvested with sickle when more than $90 \%$ grains of the panicles were matured. These were left on the field for sun drying for 2-3 days. After proper sun drying, threshing was done by pullman thresher individually for each net plot $\left(6.4 \mathrm{~m}^{2}\right)$. The total weight of grain harvested from the net plot of $6.4 \mathrm{~m} 2$ was recorded and was converted into $\mathrm{kg} \mathrm{ha}^{-1}$ at 14 per cent moisture. The data recorded were analyzed following standard statistical analysis of variance procedure as suggested by Gomez and Gomez (1984). Wherever the interaction between establishment methods and rice varieties found significant were presented in separate two way tables.

\section{Results and Discussion}

\section{Yield attributes, yield and harvest index}

Establishment methods caused significant variation in yield attributes, yield and harvest index during both the years of experiment except 1000-grain weight and harvest index for 2015 (Tables 3 and 4). Maximum number of panicles $\mathrm{m}^{-2}$ was obtained under wet DSR in 2015 which was significantly higher than rest of the establishment methods. However during 2016, DSR-aerobic recorded highest number of panicles $\mathrm{m}^{-2}$ which was comparable with DSR only. Higher number of panicle $\mathrm{m}^{-2}$ in wet DSR and DSR-aerobic method might be due to more number of seedlings $\mathrm{m}^{-2}$ which may lead to more number of shoots resulting in higher number of panicles $\mathrm{m}^{-2}$. This is consistent with the observation of Tao et al., (2016) who reported that wet direct seeded rice recorded highest panicle number per square meter among the three rice establishment methods they studied (wet direct seeded rice, dry direct seeded rice and transplanted rice). Significantly highest panicle weight was obtained under TP during 
2015 and 2016. TP resulted in higher panicle weight could be attributed to better partitioning of photosynthates from vegetative to reproductive parts. Thousand grain weight of rice did not vary significantly among four establishment methods. Dou et al., (2016) showed that water regimes like continuous flooding, saturated and aerobic could not influence 500 grain weight of rice. Akhgari and Kaviani (2011) found that planting methods like transplanting and direct seeding failed to influence 1000 grain weight. These results signify that 1000 grain weight is genetic character. TP recorded highest grain (5271 and $5124 \mathrm{~kg} \mathrm{ha}^{-1}$ ), straw (5508 and $5349 \mathrm{~kg} \mathrm{ha}^{-1}$ ) and total biological yield (10779 and $10473 \mathrm{~kg} \mathrm{ha}^{-1}$ ) during both the years which was significantly higher than all other establishment methods except for grain yield during 2015 where it was statistically at par with wet DSR (5525 $\mathrm{kg} \mathrm{ha}^{-1}$ ) and straw yield during the same year where wet DSR $\left(5304 \mathrm{~kg} \mathrm{ha}^{-1}\right.$ ) and DSR-aerobic (5169 kg ha $\left.{ }^{1}\right)$ were comparable with it. Similar results were obtained by Rana et al., (2014). Singh et al., (2001) noticed significantly higher grain and straw yields in transplanted rice than direct seeded rice both on puddled and unpuddled seedbed. Saharawat et al., (2010) observed that the yield of both dry and wet direct seeded were $0.45-0.61 \mathrm{t} / \mathrm{ha}$ lesser than transplanted rice. Chauhan et al., (2015) also found higher grain yield under transplanted rice than direct seeded rice. Harvest index was not influenced by establishment methods during 2015 but during 2016 did differ significantly and significantly higher harvest index was registered by both DSR on FIRB and TP (48.9) than rest of the establishment methods.

Perusal of data revealed that different varieties had significant effect on number of panicles $\mathrm{m}^{-2}$, panicle weight, 1000-grain weight, yield and harvest index during both the years of experiment (Tables 3 and 4).
Variety Pant Dhan 23 and Pant Shankar Dhan 3 recorded highest number of panicles $\mathrm{m}-2$ during 2015 and 2016, respectively. During 2015, Pant Dhan 23 was comparable to Pusa Basmati 1, Pant Shankar Dhan3 and Pusa 1121. During 2016, Pant Shankar Dhan 3 was statistically at par with Pant Dhan 24 and Pant Dhan 23. During 2015, Pant Shankar Dhan 1 recorded maximum panicle weight which was at pat with Pant Dhan 24, Pant Shankar Dhan 3, Pant Dhan 23 and Pant Dhan 26. During 2016, highest panicle weight was observed in Pant Shankar Dhan 3 which was at par with Pant Dhan 24, Pant Dhan 23 and Pant Shankar Dhan 1. The variety Pant Shankar Dhan 1 recorded significantly higher 1000grain weight than that of all other varieties during both years except varieties Pant Dhan 23, Pant Dhan 24 and Pant Shankar Dhan 3 which were at par with each other. Highest grain yield (5627 and $5473 \mathrm{~kg} \mathrm{ha}^{-1}$ ) was obtained with variety Pant Shankar Dhan 3 during both years which was significantly greater than rest of the varieties tested except for Pant Dhan 24 which was comparable with it in 2015. The interaction between establishment methods and varieties with respect to grain yield was found significant during both the years of experimentation (Table 4). Highest grain yield (6458 and 6590 $\mathrm{kg} \mathrm{ha}^{-1}$ ) was obtained in Pant Shankar Dhan 3 variety under TP during both the years which was significantly superior over all other combinations of establishment methods and varieties for both years except for Pant Dhan 24 in TP $\left(6198 \mathrm{~kg} \mathrm{ha}^{-1}\right)$ in 2015 which was comparable with it. Highest straw yield was obtained in variety Pant Dhan $24\left(5894 \mathrm{~kg} \mathrm{ha}^{-1}\right)$ and Pant Shankar Dhan 3 (5736 kg ha ${ }^{-1}$ ) during 2015 and 2016, respectively. The varieties Pant Shankar Dhan 3, Pant Dhan 24 and Pant Dhan 23 produced comparable straw yields during both the years. Pant Shankar Dhan 3 hybrid was significantly superior over others in terms of biological yield (11506 and $11208 \mathrm{~kg} \mathrm{ha}^{-1}$ ) during both the years except 
Pant Dhan 24 and Pant Dhan 23 which produced comparable biological yields during 2015. During both the years maximum harvest index was recorded with variety Pant Shankar Dhan 1 (49.7 and 49.4) which was at par with variety Pant Shankar Dhan 3, Govind, Pant Dhan 24 and Pant Dhan 23 during both the years. Differential performance of varieties may be attributed to their genetic makeup. Higher values of yield attributes and yield were recorded in hybrid and high yielding varieties than remaining cultivar. This might be due to ability of high yielding and hybrid varieties for better growth and better partitioning of photosynthates to reproductive parts.

Table.1 Initial soil chemical properties of upper $20 \mathrm{~cm}$ layer of the experimental field

\begin{tabular}{|c|c|c|}
\hline Particulars & Value & Method employed \\
\hline $\begin{array}{l}\text { Soil } \mathrm{pH} \\
(1: 2.5 \text { soil:water suspension })\end{array}$ & 7.7 & $\begin{array}{l}\text { Glass electrode } \mathrm{pH} \text { meter method (Jackson, } \\
\text { 1973) }\end{array}$ \\
\hline Organic carbon $(\%)$ & 0.92 & $\begin{array}{l}\text { Modified Walkley and Black method (Walkley } \\
\text { and Black, 1934) }\end{array}$ \\
\hline Available $\mathrm{N}\left(\mathrm{Kg} \mathrm{ha}^{-1}\right)$ & 232 & $\begin{array}{l}\text { Alkaline } \mathrm{KMnO}_{4} \text { method (Subbiah and Asija, } \\
\text { 1956) }\end{array}$ \\
\hline Available $\mathrm{P}\left(\mathrm{Kg} \mathrm{ha}^{-1}\right)$ & 21 & Olsen's method (Olsen et al., 1954) \\
\hline Available $\mathrm{K}\left(\mathrm{Kg} \mathrm{ha}^{-1}\right)$ & 212 & Flame photometry (Jackson, 1973) \\
\hline
\end{tabular}

Table.2 Details of seed rates of varieties under different establishment methods

\begin{tabular}{lllll}
\hline \multirow{2}{*}{ Varieties } & \multicolumn{3}{c}{ Seed rate $\left(\mathrm{kg} \mathrm{ha}^{-1}\right)$} & TP \\
\hline Pant Dhan 23 & Wet DSR & DSR-aerobic & DSR on FIRB & 30 \\
Pant Dhan 24 & 40 & 40 & 25 & 30 \\
Pant Shankar Dhan 1 & 40 & 40 & 25 & 20 \\
Pant Shankar Dhan 3 & 30 & 30 & 20 & 20 \\
Pusa Basmati 1 & 30 & 30 & 20 & 25 \\
Pusa 1121 & 35 & 35 & 20 & 25 \\
Govind & 35 & 35 & 20 & 30 \\
Pant Dhan 26 & 40 & 40 & 25 & 30 \\
\hline
\end{tabular}


Table.3 Effect of establishment methods and varieties on yield attributes, straw and biological yield and Harvest index of rice during 2015 and 2016

\begin{tabular}{|c|c|c|c|c|c|c|c|c|c|c|c|c|}
\hline \multirow[t]{2}{*}{ Treatment } & \multicolumn{2}{|c|}{ Panicles $\mathrm{m}^{-2}$} & \multicolumn{2}{|c|}{$\begin{array}{c}\text { Panicle } \\
\text { weight (g) }\end{array}$} & \multicolumn{2}{|c|}{$\begin{array}{l}\text { 1000-grain } \\
\text { weight (g) }\end{array}$} & \multicolumn{2}{|c|}{$\begin{array}{l}\text { Straw yield } \\
\left(\mathrm{kg} \mathrm{ha}^{-1}\right)\end{array}$} & \multicolumn{2}{|c|}{$\begin{array}{c}\text { Biological yield } \\
\left(\mathrm{kg} \mathrm{ha}^{-1}\right)\end{array}$} & \multicolumn{2}{|c|}{$\begin{array}{c}\text { Harvest index } \\
(\%)\end{array}$} \\
\hline & 2015 & 2016 & $\begin{array}{c}201 \\
5\end{array}$ & $\begin{array}{c}201 \\
6\end{array}$ & 2015 & 2016 & 2015 & 2016 & 2015 & 2016 & 2015 & 2016 \\
\hline \multicolumn{13}{|l|}{ Establishment methods } \\
\hline Wet DSR & 278 & 324 & 2.23 & 1.72 & 24.3 & 24.5 & 5304 & 4988 & 10201 & 9592 & 48.0 & 48.0 \\
\hline DSR-aerobic & 261 & 329 & 2.09 & 1.58 & 24.3 & 24.2 & 5169 & 4811 & 9928 & 9242 & 48.3 & 48.0 \\
\hline DSR on FIRB & 195 & 205 & 2.29 & 2.23 & 24.1 & 24.5 & 3981 & 4059 & 7803 & 7947 & 49.5 & 48.9 \\
\hline $\mathrm{TP}$ & 213 & 231 & 2.75 & 2.56 & 24.5 & 24.3 & 5508 & 5349 & 10779 & 10473 & 49.1 & 48.9 \\
\hline $\mathrm{CD}(\mathrm{P}=0.05)$ & 11.2 & 12.1 & 0.09 & 0.21 & NS & NS & 340.0 & 211 & 468 & 341 & NS & 0.6 \\
\hline \multicolumn{13}{|l|}{ Varieties } \\
\hline Pant Dhan 23 & 253 & 280 & 2.48 & 2.19 & 25.0 & 25.0 & 5570 & 5275 & 10876 & 10290 & 49.0 & 48.8 \\
\hline Pant Dhan 24 & 239 & 285 & 2.65 & 2.20 & 25.0 & 24.9 & 5894 & 5513 & 11419 & 10691 & 49.0 & 48.5 \\
\hline Pant Shankar Dhan 1 & 224 & 271 & 2.67 & 2.15 & 25.2 & 25.3 & 4841 & 4812 & 9554 & 9508 & 49.7 & 49.4 \\
\hline Pant Shankar Dhan 3 & 250 & 287 & 2.55 & 2.29 & 25.0 & 25.0 & 5880 & 5736 & 11506 & 11208 & 49.2 & 48.8 \\
\hline PB 1 & 251 & 260 & 1.73 & 1.66 & 22.7 & 22.7 & 4214 & 4073 & 7953 & 7683 & 47.3 & 47.0 \\
\hline Pusa 1121 & 249 & 268 & 1.86 & 1.80 & 22.8 & 23.0 & 4448 & 4360 & 8524 & 8356 & 48.0 & 47.8 \\
\hline Govind & 226 & 258 & 2.03 & 1.87 & 24.2 & 24.4 & 4448 & 3957 & 7832 & 7732 & 49.2 & 48.8 \\
\hline Pant Dhan 26 & 222 & 267 & 2.46 & 2.00 & 24.6 & 24.4 & 5060 & 4687 & 9762 & 9041 & 48.2 & 48.2 \\
\hline $\mathrm{CD}(\mathrm{P}=0.05)$ & 19.3 & 14.3 & 0.21 & 0.16 & 0.2 & 0.6 & 486 & 267 & 723 & 428 & 0.9 & 0.8 \\
\hline
\end{tabular}


Table.4 Interaction between different establishment methods and varieties on rice grain yield during 2015 and 2016

\begin{tabular}{|c|c|c|c|c|c|c|c|c|c|c|}
\hline \multicolumn{11}{|c|}{ Grain yield $\left(\mathrm{kg} \mathrm{ha}^{-1}\right)$ under establishment methods } \\
\hline & \multicolumn{5}{|c|}{2015} & \multicolumn{5}{|c|}{2016} \\
\hline & $\begin{array}{l}\text { Wet } \\
\text { DSR }\end{array}$ & $\begin{array}{c}\text { DSR- } \\
\text { aerobic }\end{array}$ & $\begin{array}{c}\text { DSR on } \\
\text { FIRB }\end{array}$ & TP & Mean & $\begin{array}{l}\text { Wet } \\
\text { DSR }\end{array}$ & $\begin{array}{l}\text { DSR- } \\
\text { aerobic }\end{array}$ & $\begin{array}{c}\text { DSR on } \\
\text { FIRB }\end{array}$ & $\mathrm{TP}$ & Mean \\
\hline \multicolumn{11}{|l|}{ Varieties } \\
\hline Pant Dhan 23 & 5486 & 5364 & 4462 & 5892 & 5301 & 5304 & 5133 & 4191 & 5431 & 5015 \\
\hline Pant Dhan 24 & 5936 & 5590 & 4375 & 6198 & 5525 & 5479 & 5220 & 4382 & 5629 & 5178 \\
\hline \multicolumn{11}{|l|}{ Pant Shankar } \\
\hline Dhan 1 & 5086 & 4878 & 3524 & 5364 & 4713 & 5058 & 4247 & 4072 & 5403 & 4695 \\
\hline \multicolumn{11}{|l|}{ Pant Shankar } \\
\hline Dhan 3 & 5826 & 5538 & 4684 & 6458 & 5627 & 5463 & 5300 & 4537 & 6590 & 5473 \\
\hline Pusa Basmati1 & 3854 & 3871 & 3177 & 4052 & 3739 & 3586 & 3652 & 3134 & 4069 & 3610 \\
\hline Pusa 1121 & 4357 & 4270 & 3229 & 4444 & 4075 & 3950 & 4089 & 3596 & 4347 & 3996 \\
\hline Govind & 3750 & 3664 & 3507 & 4342 & 3816 & 3644 & 3724 & 3477 & 4252 & 3774 \\
\hline Pant Dhan 26 & 4878 & 4895 & 3618 & 5416 & 4702 & 4347 & 4081 & 3715 & 5272 & 4354 \\
\hline Mean & 4897 & 4759 & 3822 & 5271 & & 4604 & 4431 & 3888 & 5124 & \\
\hline \multicolumn{4}{|c|}{$\mathrm{CD}(\mathrm{P}=0.05)$ value } & 2015 & 2016 & & & & & \\
\hline \multicolumn{4}{|c|}{ Establishment methods } & 161 & 148 & & & & & \\
\hline \multicolumn{4}{|l|}{ Varieties } & 270 & 178 & & & & & \\
\hline \multicolumn{4}{|c|}{ Two varieties at same establishment method } & 540 & 365 & & & & & \\
\hline \multicolumn{4}{|c|}{ Two establishment methods at same variety } & 529 & 363 & & & & & \\
\hline
\end{tabular}


Int.J.Curr.Microbiol.App.Sci (2017) 6(6): 297-306

Table.5 Effect of establishment methods and varieties on economics of rice during 2015 and 2016

\begin{tabular}{|c|c|c|c|c|c|c|c|c|}
\hline \multirow[t]{2}{*}{ Treatment } & \multicolumn{2}{|c|}{$\begin{array}{l}\text { Gross return } \\
\text { (Rs./ha) }\end{array}$} & \multicolumn{2}{|c|}{$\begin{array}{c}\text { Cost of } \\
\text { cultivation } \\
\text { (Rs./ha) }\end{array}$} & \multicolumn{2}{|c|}{$\begin{array}{l}\text { Net return } \\
\text { (Rs./ha) }\end{array}$} & \multicolumn{2}{|c|}{$\mathrm{B}: \mathrm{C}$ ratio } \\
\hline & 2014 & 2015 & 2014 & 2015 & 2014 & 2015 & 2014 & 2015 \\
\hline $\begin{array}{l}\text { Establishment method } \\
\text { Wet DSR }\end{array}$ & 78355 & 76657 & 28936 & 28936 & 49419 & 47721 & 1.71 & 1.65 \\
\hline DSR-aerobic & 76243 & 73796 & 27248 & 27248 & 48995 & 46549 & 1.80 & 1.71 \\
\hline DSR on FIRB & 60997 & 64461 & 27077 & 27077 & 33920 & 37384 & 1.25 & 1.38 \\
\hline $\mathrm{TP}$ & 83972 & 84552 & 33336 & 33336 & 50636 & 51216 & 1.52 & 1.53 \\
\hline Varieties & & & & & & & & \\
\hline Pant Dhan 23 & 80317 & 83114 & 28791 & 28791 & 51526 & 54323 & 1.79 & 1.89 \\
\hline Pant Dhan 24 & 83793 & 85965 & 28791 & 28791 & 55002 & 57174 & 1.91 & 1.99 \\
\hline Pant Shankar Dhan 1 & 71301 & 77714 & 30110 & 30110 & 41191 & 47604 & 1.36 & 1.58 \\
\hline Pant Shankar Dhan 3 & 85218 & 90685 & 30110 & 30110 & 55108 & 60575 & 1.83 & 2.00 \\
\hline Pusa Basmati 1 & 71512 & 60200 & 28904 & 28904 & 42608 & 31296 & 1.48 & 1.09 \\
\hline Pusa 1121 & 77807 & 66451 & 28904 & 28904 & 48904 & 37548 & 1.70 & 1.31 \\
\hline Govind & 57822 & 62527 & 28791 & 28791 & 29030 & 33736 & 1.01 & 1.18 \\
\hline Pant Dhan 26 & 71363 & 72277 & 28791 & 28791 & 42572 & 43486 & 1.48 & 1.50 \\
\hline
\end{tabular}




\section{Economics}

The data pertaining to economics of different establishment methods and rice varieties for both years are presented in table 5. The maximum gross return (Rs. 83972 and 84552 $\mathrm{ha}^{-1}$ ), cost of cultivation (Rs. $33336 \mathrm{ha}^{-1}$ for both years) and net return (Rs. 50636 and $51216 \mathrm{ha}^{-1}$ ) was obtained in TP while B:C ratio (1.80 and 1.71) was found maximum with DSR-aerobic establishment method in 2015 and 2016. Highest benefit: cost ratio under DSR-aerobic was attributed to reduced investment in field operations like land preparation and planting, irrigation water and labour than other establishment methods. Singh et al., (2001) noticed higher net returns under transplanted rice than direct seeded rice both on puddled and unpuddled seedbed in a rice-wheat cropping system. Rana et al., (2014) reported higher B: C cost ratio under direct seeding of sprouted seed than transplanting methods due to saving of irrigation water and labour.

With regard to economics of different varieties, cost of cultivation was found maximum with variety Pant Shankar Dhan 1 and Pant Shankar Dhan 3 (Rs. 30110 ha $^{-1}$ in both years. The maximum gross return (Rs. 85218 and $90685 \mathrm{ha}^{-1}$ ) and net return (Rs. 55108 and $60575 \mathrm{ha}^{-1}$ ) was recorded in variety Pant Shankar Dhan 3 in 2015 and 2016 while maximum benefit cost ratio (1.91) was recorded in Pant Dhan 24 during 2015 but during 2016, Pant Shankar Dhan 3 produced maximum $\mathrm{B}: \mathrm{C}$ ratio (2.00).

It can be concluded based on the result of two year experiment, it can be concluded that transplanted rice produces more grain and straw yield as well as gross and net return. In a situation of water scarcity and labour crunch, direct seeded-aerobic establishment method can be viable alternate method of establishment with Pant Shankar Dhan 3 and
Pant Dhan 24 because it gave greater B: C ratio. Rice hybrid Pant Shankar Dhan 3 performed better than others in terms of grain yield and gross and net return.

\section{Acknowledgement}

We gratefully acknowledge the support of ICAR-Indian Institute of Rice Research, Hyderabad for the financial assistance and Directorate of Experiment Station, G.B. Pant University of Agriculture and Technology, Pantnagar for providing necessary facilities to conduct the experiment.

\section{References}

Akhgari, H. and Kaviani, B. 2011. Assessment of direct seeded and transplanting methods of rice cultivars in the northern part of Iran. African Journal Agricultural Research. 6 (31): 6492-6498.

Anonymous. 2014. Agriculture statistics at glance 2014. Directorate of Economics and Statistics, Department of Agriculture and Cooperation, Ministry of Agriculture, Government of India, New Delhi.

Chauhan, B. S., Awan, T. H., Abugho, S. B., Evengelista, G. and Sudhir-Yadav. 2015. Effect of crop establishment methods and weed control treatments on weed management and rice yield. Field Crops Research. 172:72-84.

Deshpande, S. B., Farenbacher, J. B., Beaves, A. H. and Ray, B. W. 1971. Mollisols of Tarai region of U.P., Northern India. 1. Morphology and mineralogy, 2. Genesis and classification. Geoderma. 6: 179-201.

Duo, F., Soriano J., Taiben, R. E. and Chen, K. 2016. Soil texture and cultivar effects on rice (Oryza sativa L.) grain yield, yield components and water productivity in three water regimes. PLoS ONE. 11(3): e0150549.

Fageria, N. K. 2007. Yield physiology of rice. Journal of Plant Nutrition. 30: 843-879.

Gomez, K. A. and Gomez, A. A. 1984. Statistical procedures for agricultural 
research, Second edition, John and Wiley Sons, New York.

Jackson, M. L. 1973. Soil chemical analysis. Prentice Hall of India. Pvt. Ltd. New Delhi.

Khush, G. S. 2001. Green revolution: the way forward. Nature Reviews Genetics. 2: 815-822.

Olsen, S. R., Cole, C. V., Watanabe, F. S. and Dean, L. A. 1954. Estimation of available phosphorus in soil by extraction with sodium bicarbonate. U.S.D.A. circular no. 939. pp. 1-19.

Rana, M. M., Al Mamum, M., A., Zahan, A., Ahmed, M. N. and Mridha, M. A. J. 2014. Effect of planting methods on yield and yield attributes of short duration Aman rice. American Journal of Plant Sciences. 5: 251-255.

Saharawat, Y. S., Singh, B., Malik, R. K., Ladha, J. K., Gathala, M., Jat, M. L. and Kumar, V. 2010. Evaluation of alternative tillage and crop establishment methods in a rice- wheat rotation in North Western IGP. Field Crops Research. 116 (3): 260-267.

Sharma, P. K., Bhushan, L., Ladha, J. K., Naresh, R. K., Gupta, R. K., Balasubramanian, B. V. and Bouman, B. A. M. 2002. Crop-water relations in rice-wheat cropping under different tillage systems and water management practices in a marginally sodic, medium textured soil. In: Bouman BAM, Hengsdijk H, Hardy B, Bindraban PS, Tuong TP, Ladha JK (Eds.) Water-wise rice production. I.R.R.I, Los Banos, pp. 223-235.
Singh, A. K., Choudhury, B. U. and Bouman, B. A. M. 2002. Effects of rice establishment methods on crop performance, water use and mineral nitrogen. In: Bouman, B. A. M., Hengsdijk, H., Hardy, B., Bindraban, P. S., Tuong, T. P. and Ladha, J. K. (Eds.) Water-wise rice production. I.R.R.I, Los Banos, pp. 237-246.

Singh, D. K., Akhtar, Z., Gupta, S., Srivastava A. and Chakraborty, M. 2017. Production strategies of organic basmati rice in Tarai region of Uttarakhand, India. Organic Agriculture. 7(1): 21-30. DOI 10.1007/s13165-015-0143-1.

Singh, S., Sharma, S. N. and Prasad, R. 2001. The effect of seeding and tillage methods on productivity of rice-wheat cropping system. Soil and Tillage Research. 61:125-131.

Subbaiah, B. V., Asija, G. L. 1956. A rapid procedure for the determination of available nitrogen in soil. Current Science. 25: 259-260.

Tao, Y., Chen, Q., Peng, S., Wang, W. and Nie, L. 2016. Lower global warming potential and higher yield of wet directseeded rice in Central China. Agronomy for Sustainable Development 36: 24. doi: 10.1007/s13593-016-0361-2.

Walkley, A. and Black, I. A. 1934. An examination of Degtjareff method for determining soil organic matter and a proposed modification of the chromic acid titration method. Soil Science. 37: 29-37.

\section{How to cite this article:}

Singh, D.K., P.C. Pandey, Shanker Dutt Thapliyal and Gangadhar Nanda. 2017. Yield and Economics of Rice (Oryza sativa L.) as Influenced by Establishment Methods and Varieties under Mollisols of Pantnagar. Int.J.Curr.Microbiol.App.Sci. 6(6): 297-306. doi: https://doi.org/10.20546/ijcmas.2017.606.036 